\title{
ANALISIS ESTIMASI DAN FAKTOR-FAKTOR YANG MEMENGARUHI TINGKAT PROFITABILITAS BANK UMUM SYARIAH DI INDONESIA (STUDI KASUS PT BANK SYARIAH MANDIRI PERIODE 2008-2011)
}

\author{
Era Rizkita Alhamditia; Mohamad Heykal \\ Accounting and Finance Department, Faculty of Economics and Communication, BINUS University \\ Jln. K. H. Syahdan No.9, Palmerah, Jakarta Barat 11480 \\ m_heykal@yahoo.com
}

\begin{abstract}
The purpose of this study is to determine which among the model Return on Assets, Return on Equity, and Gross Profit Margin is best used as a model for estimation of profitability of Bank Syariah Mandiri and to determine whether the level of funding for the results, capital, operating efficiency, and liquidity influential together (simultaneously) or partially on the level of profitability of Bank Syariah Mandiri using multiple linear regression. The method used in this research is quantitative method using secondary data monthly financial statements of Bank Syariah Mandiri from period 2008-2011. The dependent variable in this study is the ROA, ROE, and GPM. Meanwhile, the independent variable is the MMR, CAR, ROA, and FDR. Results from this study are the ROA model is the best estimate that can be used to measure the profitability of Bank Syariah Mandiri seen from the influential of three independent variables that significantly effect on the ROA model. Then, the level of mudharabah financing for the results (MMR) is significant negative effect on profitability in the model of ROE, while the model is not significant for ROA and GPM. The CAR has significant negative effect on ROA and ROE models, but has no significant effect on the model GPM. BOPO is significant negative effect on ROA and GPM models, but is no significant effect on ROE. FDR is significant negative effect only on the ROA, and is not significant on the ROA and GPM model.
\end{abstract}

Keywords: syariah bank, estimation of profitability, estimation models

\begin{abstract}
ABSTRAK
Tujuan dari penelitian ini adalah untuk mengetahui model yang terbaik di antara Return on Assets, Return on Equity, dan Gross Profit Margin yang digunakan sebagai model estimasi profitabilitas Bank Syariah Mandiri dan mengetahui jika tingkat pembiayaan bagi hasil, permodalan, efisiensi operasi, dan likuiditas berpengaruh secara bersama-sama (simultan) atau parsial terhadap tingkat profitabilitas Bank Syariah Mandiri dengan menggunakan metode regresi linear berganda. Metode penelitian yang digunakan adalah metode penelitian kuantitafif dengan memakai data sekunder yaitu laporan keuangan bulanan Bank Syariah Mandiri periode 2008-2011. Variabel dependen dalam penelitian ini adalah ROA, ROE, dan GPM. Sedangkan variabel independen adalah MMR, CAR, BOPO, dan FDR. Hasil dari penelitian ini adalah model ROA merupakan estimasi terbaik yang dapat digunakan untuk mengukur profitabilitas pada Bank Syariah Mandiri dilihat dari berpengaruhnya tiga varibel independen secara signifikan pada model ROA. Kemudian, tingkat pembiayaan bagi hasil (MMR) berpengaruh negatif signifikan terhadap profitabilitas pada model ROE, sedangkan pada model ROA dan GPM tidak berpengaruh signifikan. CAR berpengaruh negatif signifikan pada model ROA dan ROE, namun tidak berpengaruh signifikan pada model GPM. BOPO berpengaruh negatif signifikan pada model ROA dan GPM, namun tidak berpengaruh signifikan pada ROE. FDR berpengaruh negatif signifikan hanya pada model ROA dan tidak signifikan pada model ROA dan GPM.
\end{abstract}

Kata kunci: bank syariah, estimasi profitabilitas, model estimasi 


\section{PENDAHULUAN}

Seperti diketahui, perkembangan perbankan syariah di Indonesia mengalami pertumbuhan yang pesat dalam satu dekade terakhir, yaitu sejak berdirinya Bank Muamalat Indonesia sebagai bank umum syariah pertama pada 1992 dan dikeluarkannya UU No.7/1992, tentang perbankan. Kemudian diikuti oleh Bank Syariah Mandiri pada 1999, dan Bank Mega Syariah pada 2003. Perkembangaan ini terus diikuti oleh beredarnya jaringan kantor perbankan syariah, khususnya bank umum syariah, yang tersebar di seluruh wilayah Indonesia, sesuai dengan data statistik berikut.

Tabel 1 Jaringan Kantor Bank Umum Syariah

\begin{tabular}{lccccccc}
\hline \multicolumn{7}{c}{ Jaringan kantor bank umum syariah } \\
\hline & $\mathbf{2 0 0 5}$ & $\mathbf{2 0 0 6}$ & $\mathbf{2 0 0 7}$ & $\mathbf{2 0 0 8}$ & $\mathbf{2 0 0 9}$ & $\mathbf{2 0 1 0}$ & $\mathbf{2 0 1 1}$ \\
\hline Jumlah Bank & 3 & 3 & 3 & 3 & 5 & 6 & 11 \\
Jumlah Kantor & 304 & 349 & 401 & 581 & 711 & 1215 & 1401 \\
\hline
\end{tabular}

Sumber: Bank Indonesia (Statistik Perbankan Syariah, Desember 2011)

Pada 1998 pemerintah semakin mengadopsi perkembangan perbankan syariah dengan dikeluarkannya UU No.10/1998 yang menunjukkan bahwa bank umum dapat melakukan usaha menyediakan pembiayaan dan/atau melakukan kegiatan lain berdasarkan 'Prinsip Syariah', sesuai dengan ketentuan yang telah ditetapkan oleh Bank Indonesia. Selain dikeluarkannya undang-undang, hal lain yang mendukung perkembangan bank syariah di Indonesia adalah pada 16 Desember 2003, majelis ulama mengeluarkan Fatwa MUI yang menyatakan bahwa bunga bank adalah haram. Hal ini tentunya telah mendorong sejumlah bank untuk mulai membuka unit usaha berdasarkan prinsip syariah. Karena pesatnya perkembangan industri perbankan syariah, maka pada akhirnya perbankan syariah memiliki landasan hukum yang memadai, yaitu dengan diberlakukannya UU N0.21/2008 tentang Perbankan Syariah pada 16 Juli 2008. Perbedaan utama perbankan syariah dengan perbankan konvensional adalah berkaitan dengan pendapatan berdasarkan produk pembiayaan. Dalam perbankan konvesional dikenal produk pembiayaan berdasarkan konsep kredit yang menggunakan sistem suku bunga, maka dalam perbankan syariah dikenal untuk produk pembiayaan mengikuti prinsip syariah yaitu menggunakan sistem bagi hasil dan sistem jual-beli. Dalam melakukan akad bagi-hasil yang menggunakan metode pemenuhan kebutuhan permodalan, perbankan syariah tidak menggunakan metode pinjam-meminjam uang dalam rangka kegiatan komersial, karena setiap pinjam-meminjam uang yang dilakukan dengan persyaratan atau janji pemberian imbalan adalah termasuk riba. Oleh karena itu, mekanisme operasional perbankan syariah dijalankan dengan menggunakan prinsip bagi hasil perbankan syariah yaitu : mudharabah (prinsip kepercayaan) dan musyarakah (prinsip kerja sama). Sistem pembiayaan dengan basis bagi hasil memiliki risiko tinggi dalam hal kerugian yang dapat terjadi dalam kurun waktu pembiayaan tersebut sehingga dapat menurunkan laba perusahaan karena pembiayaan bagi hasil tidak hanya bersifat berbagi untung tetapi juga berbagi rugi. Karena itu, dalam menilai kinerja bank syariah tidak hanya menitikberatkan kepada kemampuan bank syariah dalam menghasilkan laba tetapi juga pada kepatuhan terhadap prinsipprinsip syariah dan tujuan bank syariah tersebut. Maka untuk mencapai tingkat efisiensi bank syariah dalam menghasilkan profit tinggi harus dilihat juga berdasarkan tingkat pengaruh dari kinerja operasional bank tersebut yang dapat dilihat dari tingkat pembiayaan, perputaran permodalan, efisiensi operasional bank, dan likuiditas bank tersebut. Berdasarkan uraian di atas, maka peneliti tertarik untuk melakukan kajian yang lebih mendalam tentang adanya pengaruh tingkat pembiayaan bagi hasil, permodalan, efisiensi operasional, dan likuiditas terhadap profitabilitas Bank Umum Syariah dengan penelitian yang judul "Analisis Estimasi dan Faktor-faktor Yang Berpengaruh terhadap Tingkat Profitabilitas Bank Umum Syariah Periode 2008-2011; Studi Kasus PT Bank Syariah Mandiri Periode 2008-20011. 


\title{
Pengertian Efisiensi
}

Efisiensi merupakan kemampuan dalam menjalankan tugas dengan baik dan tepat dengan tidak membuang waktu, tenaga, dan biaya. Sementara efisiensi operasional dihubungkan dengan efisiensi berdasarkan dengan kegiatan operasional yang dilakukan oleh perusahaan untuk dapat mencapai tujuannya.

\section{Pengertian Likuiditas}

Berdasarkan pengertian dari Bank Indonesia, yang dimaksud dengan likuiditas adalah kemampuan untuk memenuhi seluruh kewajiban yang harus dilunasi segera dalam waktu yang singkat. Perusahaan yang likuiditasnya baik secara umum dapat: menjalankan transaksi bisnisnya dengan baik, mengatasi kebutuhan dana yang mendesak, memuaskan permintaan nasabah akan pinjaman, dan memberikan fleksibilitas dalam meraih investasi yang menarik.

\section{Pengertian Profitabilitas}

Profitabilitas merupakan kemampuan suatu perusahaan dalam menghasilkan laba selama periode tertentu. Dalam dunia perbankan bisa dikatakan bahwa profitabilitas merupakan ukuran khusus sebuah bank, yang di dalamnya manajemen dari bank berusaha untuk memaksimalkan nilai perusahaan di mata para pemegang saham.

\section{METODE PENELITIAN}

Pengertian tentang bank syariah dan bank umum syariah telah dijelaskan di dalam pasal 1 UU nomor 21 tahun 2008 sebagai berikut:

"Bank Syariah adalah bank yang menjalankan kegiatan usahanya berdasarkan prinsip syariah dan menurut jenisnya terdiri atas Bank Umum Syariah dan Bank Pembiayaan Rakyat Syariah. Sedangkan Bank Umum Syariah adalah bank syariah yang dalam kegiatannya tidak memberikan jasa dalam lalu lintas pembayaran"

Sedangkan yang dimaksud dengan prinsip syariah seperti yang dijelaskan dalam pasal 1 ayat 13 UU no 10 tahun 1998 adalah:

\begin{abstract}
"Prinsip syariah adalah aturan perjanjian berdasarkan hukum Islam antara bank dan pihak lain untuk penyimpanan dana dan atau pembiayaan kegiatan usaha, atau kegiatan lainya yang dinyatakan sesuai dengan syariah, atara lain pembiayaan berdasarkan prinsip bagi hasil (mudharabah), pembiayaan berdasarkan prinsip penyertaan modal (musyarakah), prinsip jual beli barang dengan memperoleh keuntungan (murabahah), atau pembiayaan barang modal berdasarkan prinsip sewa murni tanpa pilihan (ijarah) atau dengan adanya pilihan pemindahan kepemilikan atas barang yang disewa dari pihak bank oleh pihak lain (ijarah wa iqtina)."
\end{abstract}

Menurut Karim (2004), pada dasarnya produk yang ditawarkan oleh perbankan syariah dapat dibagi menjadi tiga bagian besar, yaitu: (1) Produk penyaluran Dana (financing); bank syariah menyalurkan dananya kepada nasabah secara garis besar dengan produk pembiayaan syariah, yang ketentuan ini tentunya berbeda dengan pembiayaan atau biasa disebut pemberian kredit pada bank konvensional. Hal yang membedakan disini adalah sistem bunga pada bank konvensional dan sistem bagi hasil pada bank syariah. (2) Produk Penghimpunan Dana (Funding); penghimpunan dana pada bank syariah dapat berupa giro, tabungan, dan deposito. Prinsip operasional syariah yang diterapkan dalam penghimpunan dana masyarakat adalah prinsip Wadi'ah (diterapkan pada produk giro) dan 
Mudharabah (diaplikasikan pada penyimpanan atau deposan yang bertindak sebagai pemilik modal dan bank sebagai pengelola). (3) Produk jasa (service); bank syariah dapat melakukan berbagai pelayanan jasa perbankan kepada nasabah dengan mendapatkan imbalan berupa sewa atau keuntungan. Jasa perbankan tersebut antara lain adalah Sharf (jual beli valuta asing) dan Ijarah (sewa) seperti penyewaan barang, mesin-mesin, barang yang telah dimiliki oleh bank maupun barang yang diperoleh dengan menyewa dari pihak lain

Dalam melaksanakan kegiatannya memberikan pembiayaan, bank syariah memiliki perbedaan mencolok dengan bank konvensional yaitu pembiayaan bagi hasil yang erupaka salah satu prinsip penyaluran dana bank syariah. Pembiayaan bagi hasil terdapat dua macam yaitu mudharabah dan musyarakah.

\section{Mudharabah}

Pengertian mudharabah menurut Harahap, Wiroso, dan Yusuf (2010:423) adalah sebagai berikut. Mudharabah merupakan suatu akad kerja sama kemitraan antara penyedia dana usaha (shahibul mal) dengan pengelolaan danan/ manajemen usaha (mudharib) untuk memperoleh hasil usaha dengan pembagian hasil usaha sesuai porsi (nisbah) yang disepakati bersama sejak awal.

\section{Musyarakah}

Pengertian musyarakah menurut Harahap, Wiroso, dan Yusuf (2010:474) adalah sebagai berikut. Musyarakah adalah akad kerja sama diantara para pemilik modal yang mencampurkan modal mereka untuk tujuan mencari keuntungan.

\section{Rasio Keuangan}

Najmudin (2011) menyatakan bahwa rasio menggambarkan suatu hubungan atau perimbangan (mathematical relationship) antara jumlah tertentu dengan jumlah yang lain. Alat analisis ini akan dapat menjelaskan atau memberikan gambaran tentang analis tentang baik buruknya keadaan atau posisi keuangan suatu perusahaan, utamanya apabila angka rasio tersebut dibandingkan dengan angka rasio pembanding yang digunakan sebagai standar.

Berdasarkan teori yang dijabarkan oleh Copeland dan Wetson (1995) dalam Muhammad (2011), dalam menganalisis keuangan suatu perusahaan terdapat pengelompokan terlebih dahulu terhadap ukuran-ukuran yang ada menjadi: ukuran kinerja, ukuran efisiensi operasional, dan ukuran kebijakan keuangan. Walaupun analisis rasio dapat menjadi alat analisis yang sangat berguna dan efisien, ia juga memiliki beberapa kelemahan yang patut diketahui, di antaranya: pertama, analisis rasio tersusun atas data akuntansi yang sangat dipengaruhi oleh prosedur pembuatannya. Sehingga dalam melihat nilai rasio, dilihat pula prosedur dalam perhitungannya seperti pemakaian metode akuntansi yang digunakan oleh setiap perusahaan. Kedua, analisis rasio hanya menyediakan gambaran umum kondisi keuangan perusahaan. Jika ingin mengetahui lebih mendalam dan lebih detail, akan lebih baik jika langsung melakukan penyelidikan akuntansi keuangan perusahaan. Ketiga, analisis rasio membutuhkan penafsiran yang tepat dalam mengintepretasikannya. Pihak yang menafsirkan harus memiliki pengetahuan terkait batas nilai yang baik dan yang buruk bagi suatu standar rasio. Keempat, analisis rasio akan menjadi lebih berguna jika dilakukan komparasi dengan kompetitor atau industri sejenis dan dikaitkan dengan faktor strategis lainnya.

Terdapat beberapa penelitian berkaitan dengan topik penelitian ini, di antaranya adalah yang dilakukan oleh Raharyo (2011) bertujuan untuk mengetahui apakah terdapat perbedaan tingkat pertumbuhan laba serta perbedaan perubahan tingkat kesehatan yang ada pada bank umum syariah. Adapun yang menjadi objek penelitian adalah antara Bank Syariah Mandiri dengan Bank Muamalat Indonesia. Penelitian ini juga ingin melihat bagaimana pengaruh perubahan variabel tingkat kesehatan 
bank terhadap tingkat pertumbuhan laba pada Bank Syariah Mandiri dan Bank Muamalat Indonesia. Variabel dependen yang terdapat dalam penelitian ini adalah pertumbuhan laba. Sedangkan variabel independennya adalah perubahan variabel CAR (Capital Adequacy Ratio), NPF (Non-Performing Financing), BOPO (Biaya Oprerasional terhadap Pendapatan Operasional), FDR (Financing to Deposit Ratio), dan GWM (Giro Wajib Minimum). Hasil penelitian ini menunjukan bahwa tidak terdapat perbedaan perubahan variabel tingkat kesehatan bank dan tidak terdapat perbedaan pertumbuhan laba antara Bank Syariah Mandiri dan Bank Muamalat Indonesia. Pada Bank Syariah Mandiri hanya perubahan variabel BOPO yang berpengaruh signifikan terhadap pertumbuhan laba. Sedangkan pada Bank Muamalat Indonesia hanya perubahan variabel BOPO dan CAR yang berpengaruh signifikan terhadap pertumbuhan laba. Selain juga terdapat penelitian lain, yaitu penelitian yang dilakukan oleh Muhammad (2011) untuk mengetahui bagaimana pengaruh faktorfaktor internal spesifik bank maupun faktor-faktor eksternal bank yang diwakili oleh faktor-fakor terkait kondisi makro ekonomi terhadap profitabilitas Bank Umum Syariah di Indonesia periode 20052009. Selain itu, penelitian ini juga bertujuan untuk mencari model estimasi yang terbaik untuk estimasi profit. Variabel yang digunakan adalah ROA (Return on Assets), ROE (Return on Equity), NIM (Net Interest Margin), CAR (Capital Adequacy Ratio), LLR (Loan Loss Ratio), OER (Operating Expense Ratio), FDR (Financing to Deposit Ratio), dan CPI (Consumer Price Index). Metode regresi linear berganda digunakan pada tiga model estimasi yang berbeda, yakni model ROE, ROA, dan NIM. Hasilnya adalah model estimasi terbaik di dalam penelitian ini adalah model ROE (Return On Equity). Kemudian OER (Operating Expense Ratio), berpengaruh negatif signifikan di semua model. Selanjutnya LLR (Loan Loss Ratio) berpengaruh negatif signifikan, namun hanya pada model ROA (Retun On Assets) dan NIM (Net Interest Margin). Kemudian CPI (Consumer Price Index) berpengaruh negatif signifikan hanya pada model ROE (Return On Equity). Setelah itu, variabel dummy (krisis finansial global tahun 2008) hanya berpengaruh negatif signifikan pada model ROA (Return On Assets). Sedangkan CAR (Capital Adequacy Ratio) dan FDR (Financing to Deposit Ratio) tidak berpengaruh signifikan.

Metode penelitian yang digunakan dalam penelitian ini adalah metode kuantitatif dengan menggunakan data sekunder yang diambil dari web Bank Syariah Mandiri dan Bank Indonesia berupa laporan keuangan bulanan Bank Syariah Mandiri tahun 2008-2011. Peneliti juga mengembangkan beberapa hipotesis dalam penelitian ini, yaitu hipotesis yang akan diuji dan dibuktikan dalam penelitian ini berkaitan dengan ada tidaknya pengaruh dari variabel-variabel independen terhadap variabel dependen. Pengujian hipotesis yang dilakukan ini merupakan pengujian hipotesis null (Ho) yang menyatakan bahwa koefisien korelasi tidak berarti atau tidak signifikan sedangkan hipotesis alternatif (Ha) menyatakan bahwa koefisien korelasinya berarti atau signifikan. Adapun perumusan dari hipotesa yang dikembangkan dalam penelitian ini adalah sebagai berikut.

\section{Secara Parsial}

\section{Tingkat Pembiayaan Bagi Hasil}

Ho H $_{\text {. }}$ Tingkat pembiayaan bagi hasil tidak berpengaruh terhadap tingkat profitabilitas Bank Syariah Mandiri

Ha a $_{\text {: }}$ Tingkat pembiayaan bagi hasil berpengaruh terhadap tingka profitabilitas Bank Syariah Mandiri

\section{Tingkat Permodalan}

Ho $_{2}$ : Tingkat Permodalan (CAR - Capital Adequacy Ratio) tidak berpengaruh terhadap tingkat profitabilitas Bank Syariah Mandiri

Ha $_{2}$ : Tingkat Permodalan (CAR - Capital Adequacy Ratio ) berpengaruh terhadap tingkat profitabilitas Bank Syariah Mandiri 


\section{Tingkat Efisiensi Operasi}

Ho $_{3}$ : Tingkat Efisiensi Operasi (BOPO - Biaya Operasional pada Pendapatan Operasional) tidak berpengaruh terhadap tingkat profitabilitas Bank Syariah Mandiri

Ha H $_{3}$ Tingkat Efisiensi Operasi (BOPO - Biaya Operasional pada Pendapatan Operasional) berpengaruh terhadap tingkat profitabilitas Bank Syariah Mandiri

\section{Tingkat Likuiditas}

Ho $_{4}$ : Tingkat Likuiditas (FDR - Financing to Deposit Ratio) tidak berpengaruh terhadap tingkat profitabilitas Bank Syariah Mandiri

Ha 4 : Tingkat Likuiditas (FDR - Financing to Deposit Ratio) berpengaruh terhadap tingkat profitabilitas Bank Syariah Mandiri

\section{Secara Keseluruhan}

Ho5: Tingkat pembiayaan bagi hasil, permodalan, efisiensi operasi, dan likuiditas tidak berpengaruh terhadap tingkat profitabilitas Bank Syariah Mandiri

Ha: Tingkat pembiayaan bagi hasil, permodalan, efisiensi operasi, dan likuiditas berpengaruh terhadap tingkat profitabilitas Bank Syariah Mandiri

Tabel 1 Rangkuman Hipotesis Penelitian

\begin{tabular}{|c|c|}
\hline \multicolumn{2}{|r|}{ HIPOTESIS } \\
\hline $\mathrm{Ho}_{1}$ & $\begin{array}{l}\text { Tingkat pembiayaan bagi hasil tidak berpengaruh terhadap tingkat profitabilitas } \\
\text { Bank Syariah Mandiri }\end{array}$ \\
\hline & Tingkat pembiayaan bagi hasil berpengaruh terhadap tingkat profitabilitas Bank \\
\hline $\mathrm{Ha}_{1}$ & Syariah Mandiri \\
\hline $\mathrm{Ho}_{2}$ & $\begin{array}{l}\text { Tingkat Permodalan (CAR - Capital Adequacy Ratio) tidak berpengaruh } \\
\text { terhadap tingkat profitabilitas Bank Syariah Mandiri }\end{array}$ \\
\hline $\mathrm{Ha}_{2}$ & $\begin{array}{l}\text { Tingkat Permodalan (CAR - Capital Adequacy Ratio) berpengaruh terhadap } \\
\text { tingkat profitabilitas Bank Syariah Mandiri }\end{array}$ \\
\hline $\mathrm{Ho}_{3}$ & $\begin{array}{l}\text { Tingkat Efisiensi Operasi (BOPO - Biaya Operasional pada Pendapatan } \\
\text { Operasional) tidak berpengaruh terhadap tingkat profitabilitas Bank Syariah } \\
\text { Mandiri }\end{array}$ \\
\hline $\mathrm{Ha}_{3}$ & $\begin{array}{l}\text { Tingkat Efisiensi Operasi (BOPO - Biaya Operasional pada Pendapatan } \\
\text { Operasional) berpengaruh secara terhadap tingkat profitabilitas Bank Syariah } \\
\text { Mandiri }\end{array}$ \\
\hline $\mathrm{Ho}_{4}$ & $\begin{array}{l}\text { Tingkat Likuiditas (FDR - Financing to Deposit Ratio) tidak berpengaruh } \\
\text { terhadap tingkat profitabilitas Bank Syariah Mandiri }\end{array}$ \\
\hline $\mathrm{Ha}_{4}$ & $\begin{array}{l}\text { Tingkat Likuiditas (FDR - Financing to Deposit Ratio) berpengaruh terhadap } \\
\text { tingkat profitabilitas Bank Syariah Mandiri }\end{array}$ \\
\hline Ho5 & $\begin{array}{l}\text { Tingkat pembiayaan bagi hasil, permodalan, efisiensi operasi, dan likuiditas } \\
\text { tidak berpengaruh terhadap tingkat profitabilitas Bank Syariah Mandiri }\end{array}$ \\
\hline $\mathrm{Ha} 5$ & $\begin{array}{l}\text { Tingkat pembiayaan bagi hasil, permodalan, efisiensi operasi, dan likuiditas } \\
\text { berpengaruh terhadap tingkat profitabilitas Bank Syariah Mandiri }\end{array}$ \\
\hline
\end{tabular}

Sumber: Hasil Olahan

Dalam melakukan pengujian data, penulis melakukan uji statistik dengan menggunakan regresi berganda yang dianalisa dengan SPSS 17 serta melakukan uji hipotesis. Variabel yang digunakan dalam penelitian ini adalah Return on Asset (ROA), Return on Equity (ROE), dan Gross Profit Margin (GPM) sebagai variabel dependen dan Mudharabah Musyarakah Ratio (MMR), Capital Adequacy Ratio (CAR), Biaya Operasional terhadap Pendapatan Operasional (BOPO), dan Financing 
to Deposit Ratio (FDR) sebagai variabel independen. Metode penyajian data yang digunakan oleh penulis adalah dalam bentuk tabel dan narasi untuk menjelaskan hasil analisis terhadap laporan keuangan bulanan Bank Syariah Mandiri sebagai objek penelitian pada periode tahun 2008-2011.

\section{HASIL DAN PEMBAHASAN}

Pada penelitian ini akan dianalisis dan berbagai hasil pengolahan data yang telah dilakukan untuk menguji rumusan masalah yang dihadapi dan menguji hipotesis yang telah dibuat sebelumnya, sehingga akan ditemukan jawaban dari rumusan masalah dan apakah seluruh hipotesis tersebut diterima atau ditolak. Pengujian hipotesis dalam penelitian ini menggunakan tingkat kepercayaan sebesar 95\% sehingga sig. $=5 \%$. Analisis dilakukan terhadap semua variabel, baik variabel dependen untuk profitabilitas (ROA, ROE, GPM) maupun variabel independen ( MMR, CAR, BOPO, FDR). Uji statistik yang akan dilakukan di dalam penelitian ini adalah uji $\mathrm{F}$ dan uji $\mathrm{t}$ untuk menguji adanya pengaruh secara simultan atau parsial variabel bebas (independen) terhadap variabel terikat (dependen), dan uji koefisien determinasi $\left(\mathrm{R}^{2}\right)$ untuk melihat seberapa besar variabel independen dapat menjelaskan varibel dependen dalam persamaan model yang akan diteliti.

Tabel 2 Hasil Uji F

\begin{tabular}{cccc} 
Model & Nilai $\mathbf{F}_{\text {hitung }}$ & Nilai $\mathbf{F}_{\text {tabel }}$ & Sig. \\
\hline ROA & 10,027 & 2,53 & 0,000 \\
ROE & 36,513 & 2,53 & 0,000 \\
GPM & 0,000 & 2,53 & 0,000 \\
\hline
\end{tabular}

Berdasarkan hasil uji di atas, nilai $\mathrm{F}_{\text {hitung }}$ pada model ROA dan ROE secara keseluruhan berada di atas 2,53 atau $F_{\text {hitung }}>F_{\text {tabel }}$ sehingga dengan demikian keputusannya adalah menolak Ho dan menerima Ha, bahwa variabel independen berpengaruh secara bersama-sama (simultan) dan signifikan terhadap variabel dependen, yaitu ROA dan ROE. Sedangkan model GPM memiliki nilai $F_{\text {hitung }}<F_{\text {tabel }}$ sehingga keputusannya adalah menolak Ha dan menerima Ho, dengan variabel independen tidak berpengaruh secara bersama-sama (simultan) dan signifikan terhadap variabel dependennya, yaitu GPM.

Uji $t$ dilakukan dengan membandingkan nilai $t_{\text {tabel }}$ dengan nilai $t_{\text {hitung. }}$. Dalam mencari nilai $t_{\text {tabel }}$ penelitian digunakan taraf kepercayaan $95 \%$, maka $t_{\text {tabel }}$ yang dibaca adalah $t_{\text {tabel }}$ pada $1 / 2 \alpha$ atau $1 / 2(0,05)$, yaitu $t_{\text {tabel }}$ pada 0,025 dengan nilai $t_{\text {tabel }}$ pada $\alpha 0,025=2,000$. Hipotesis yang akan diuji adalah hipotesis null (Ho) dan hipotesis alternatif (Ha), dengan hipotesis Ho adalah variabel independen tidak berpengaruh secara parsial dan signifikan terhadap variabel dependen dan hipotesis Ha berarti variabel independen berpengaruh secara parsial dan signifikan terhadap variabel dependen. Suatu variabel dapat dikatakan signifikan jika nilai Sig. pada tabel bernilai dibawah 0,05 .

Tabel 3 Hasil Uji t pada ROA

\begin{tabular}{ccccc}
\hline Model & $\begin{array}{c}\text { Nilai } \\
\mathbf{t}_{\text {hitung }}\end{array}$ & $\begin{array}{c}\text { Nilai } \\
\mathbf{t}_{\text {tabel }}\end{array}$ & Sig. & Keputusan \\
\hline MMR & 1,040 & 2,000 & 0,304 & Menerima Ho \& signifikan \\
CAR & $-4,112$ & $-2,000$ & 0,000 & Menerima Ha \& signifikan \\
BOPO & $-4,209$ & $-2,000$ & 0,000 & Menerima Ha \& signifikan \\
FDR & $-3,130$ & $-2,000$ & 0,003 & Menerima Ha \& signifikan \\
\hline
\end{tabular}


Pada model CAR, BOPO, dan FDR menolak Ho dan menerima Ha yaitu variabel independen (CAR, BOPO, FDR) berpengaruh secara parsial dan signifikan terhadap variabel dependen (ROA). Sedangkan pada model MMR menolak Ha dan menerima Ho yaitu variabel independen (MMR) tidak berpengaruh secara parsial dan signifikan terhadap variabel dependen (ROA).

Tabel 4 Hasil Uji t pada ROE

\begin{tabular}{ccccl}
\hline Model & $\begin{array}{c}\text { Nilai } \\
\mathbf{t}_{\text {hitung }}\end{array}$ & $\begin{array}{c}\text { Nilai } \\
\mathbf{t}_{\text {tabel }}\end{array}$ & Sig. & \multicolumn{1}{c}{ Keputusan } \\
\hline MMR & $-4,792$ & $-2,000$ & 0,000 & Menerima Ha \& signifikan \\
CAR & $-5,631$ & $-2,000$ & 0,000 & Menerima Ha \& signifikan \\
BOPO & 1,301 & 2,000 & 0,200 & Menerima Ho \& tidak signifikan \\
FDR & $-0,200$ & $-2,000$ & 0,842 & Menerima Ho \& tidak signifikan \\
\hline
\end{tabular}

Pada model MMR dan CAR menolak Ho dan menerima Ha yaitu variabel independen (MMR dan CAR) berpengaruh secara parsial dan signifikan terhadap variabel dependen (ROE). Sedangkan pada model BOPO dan FDR menolak Ha dan menerima Ho yaitu variabel independen (BOPO dan FDR) tidak berpengaruh secara parsial dan signifikan terhadap variabel dependen (ROE).

Tabel 5 Hasil Uji t pada GPM

\begin{tabular}{ccccl}
\hline Model & Nilai t & $\begin{array}{c}\text { Nilai } \\
\mathbf{t}_{\text {tabel }}\end{array}$ & Sig. & \multicolumn{1}{c}{ Keputusan } \\
\hline MMR & 0,000 & 2,000 & 1,000 & Menerima Ho \& tidak signifikan \\
CAR & 0,000 & 2,000 & 1,000 & Menerima Ho \& tidak signifikan \\
BOPO & $-3,101$ & $-2,000$ & 0,000 & Menerima Ha \& signifikan \\
FDR & 0,000 & 2,000 & 1,000 & Menerima Ho \& tidak signifikan \\
\hline
\end{tabular}

Pada model BOPO menolak Ho dan menerima Ha, dengan variabel independen BOPO berpengaruh secara parsial dan signifikan terhadap variabel dependen (GPM). Sedangkan pada ketiga model lainnya yaitu MMR, CAR, dan FDR menolak Ha dan menerima Ho, dengan variabel independen (MMR, CAR, dan FDR) tidak berpengaruh secara parsial dan signifikan terhadap variabel dependen (GPM).

Tabel 6 Hasil Uji Regresi pada MMR

\begin{tabular}{lcc}
\hline \multicolumn{1}{c}{ Model } & Sig. & Coefficients \\
\hline ROA & 0,304 & 0,009 \\
ROE & 0,000 & $-0,458$ \\
GPM & 1,000 & $-2,766$ \\
\hline
\end{tabular}


Hasil regresi menunjukkan bahwa nilai signifikasi MMR pada model ROA, ROE, dan GPM adalah sebesar 0,$304 ; 0,000 ; 1,000$. Berdasarkan hasil tersebut, maka dapat dilihat bahwa model MMR berpengaruh signifikan pada profitabilitas Bank Syariah Mandiri untuk model ROE, karena nilai signifikansinya lebih kecil dari alpha yakni 0,05. Akan tetapi, MMR tidak berpengaruh secara signifikan pada model ROA dan GPM, karena nilai signifikasinya berada di atas nilai alpha 0,05. Berdasarkan hasil tersebut, dapat disimpulkan bahwa hipotesis semula $\left(\mathrm{Ha}_{1}\right)$ yang menyatakan bahwa MMR berpengaruh signifikan terhadap profitabilitas Bank Syariah Mandiri terbukti untuk model ROE, namun tidak terbukti untuk model ROA dan GPM.

Tabel 7 Hasil Uji Regresi pada CAR

\begin{tabular}{ccc}
\hline Model & Sig. & Coefficients \\
\hline ROA & 0,000 & $-0,078$ \\
ROE & 0,000 & $-1,223$ \\
GPM & 1,000 & 3,505 \\
\hline
\end{tabular}

Berdasarkan hasil regresi, CAR memiliki nilai signifikasi sebesar 0,$000 ; 0,000 ; 1,000$. Hal ini menunjukkan bahwa CAR berpengaruh secara signifikan pada profitabilitas Bank Syariah Mandiri untuk model ROA dan ROE karena nilai signifikasinya lebih kecil daripada nilai alpha yaitu 0,05. Akan tetapi, CAR tidak memiliki pengaruh signifikan pada model GPM karena nilai signifikansinya berada di atas nilai alpha. Oleh karena itu, hipotesis semula, yaitu hipotesis $\mathrm{Ha}_{2}$, yang menyatakan bahwa CAR berpengaruh secara signifikan terhadap profitabilitas Bank Syariah Mandiri terbukti pada model ROE dan ROA, namun tidak terbukti pada model GPM.

Tabel 8 Hasil Uji Regresi pada BOPO

\begin{tabular}{ccc} 
Model & Sig. & Coefficients \\
\hline ROA & 0,000 & $-0,012$ \\
ROE & 0,200 & 0,042 \\
GPM & 0,000 & $-1,000$ \\
\hline
\end{tabular}

Berdasarkan hasil perhitungan regresi ditunjukkan bahwa nilai signifikasi BOPO pada model ROA, ROE, dan GPM adalah sebesar 0,$000 ; 0,200 ; 0,000$. Berdasarkan hasil tersebut, maka dapat dilihat bahwa model MMR berpengaruh signifikan pada profitabilitas Bank Syariah Mandiri untuk model ROA dan GPM, karena nilai signifikasinya lebih kecil dari alpha yakni 0,05. Akan tetapi, BOPO tidak berpengaruh secara signifikan pada model ROE, karena nilai signifikasinya berada di atas nilai alpha 0,05 . Berdasarkan hasil tersebut, dapat disimpulkan bahwa hipotesis semula $\left(\mathrm{Ha}_{1}\right)$ yang menyatakan bahwa BOPO berpengaruh negatif signifikan terhadap profitabilitas Bank Syariah Mandiri terbukti untuk model ROA dan GPM, tetapi tidak terbukti untuk model ROE. 
Tabel 9 Hasil Uji Regresi pada FDR

\begin{tabular}{ccc}
\hline Model & Sig. & Coefficients \\
\hline ROA & 0,003 & $-0,013$ \\
ROE & 0,842 & 0,010 \\
GPM & 1,000 & 2,129 \\
\hline
\end{tabular}

Variabel FDR memiliki nilai signifikasi sebesar 0,$003 ; 0,842 ; 1,000$. Hal ini menunjukan bahwa FDR berpengaruh secara signifikan pada profitabilitas Bank Syariah Mandiri untuk model ROA, karena nilai signifikasinya lebih kecil daripada nilai alpha yaitu 0,05. Akan tetapi, FDR tidak memiliki pengaruh signifikan pada model ROE dan GPM karena nilai signifikansinya berada di atas nilai alpha. Oleh karena itu, hipotesis semula, yaitu hipotesis $\mathrm{Ha}_{2}$ yang menyatakan bahwa FDR berpengaruh secara signifikan terhadap profitabilitas Bank Syariah Mandiri terbukti pada model ROA, namun tidak terbukti pada model ROE dan GPM.

Berdasarkan hasil analisis regresi, dapat dilihat juga dari jumlah variabel independen yang berpengaruh signifikan terhadap variabel dependen untuk melihat estimasi terbaik profitabilitas Bank Syariah mandiri. ROA memiliki tiga variabel independen (BOPO, CAR, dan FDR) yang berpengaruh signifikan terhadap variabel dependen (ROA) dibanding dengan model lainnya. Hal ini menunjukkan bahwa ROA mampu dijelaskan dengan baik oleh BOPO, CAR, dan FDR. Oleh karena itu, penulis menyimpulkan bahwa dalam penelitian ini model ROA merupakan model yang paling baik untuk mengestimasi profitabilitas Bank Syariah Mandiri.

\section{SIMPULAN}

Penelitian ini dilakukan dengan tujuan untuk mengetahui model terbaik di antara ROA, ROE, dan GPM untuk digunakan sebagai model estimasi profitabilitas pada Bank Syariah Mandiri dan mengetahui jika terdapat pengaruh tingkat pembiayaan bagi hasil (revenue sharing), permodalan, efisiensi operasi, dan likuiditas terhadap tingkat profitabilitas pada Bank Syariah Mandiri.

Berdasarkan seluruh pengujian yang telah dilakukan, maka dapat dibuat beberapa kesimpulan dari penelitian ini. Pertama, pada Bank Syariah Mandiri, tingkat pembiayaan bagi hasil (MMR), permodalan (CAR), efisiensi operasi (BOPO), dan likuiditas (FDR) berpengaruh secara bersama-sama (simultan) terhadap tingkat profitabilitas Bank Syariah Mandiri. Hal tersebut dapat dilihat dari hasil regresi yang menunjukkan bahwa dua dari tiga model estimasi profitabilitas memiliki nilai $F_{\text {hitung }}$ yang lebih kecil daripada $0,05(\alpha)$ yaitu pada model ROA dan ROE. Karena itu, dapat diartikan bahwa pada kedua model tersebut (ROA dan ROE) memiliki variabel independen (MMR, CAR, BOPO, dan FDR) yang secara bersama-sama (simultan) memiliki pengaruh signifikan terhadap variabel dependennya. Kedua, dari hasil regresi, tingkat pembiayaan bagi hasil (MMR) berpengaruh negatif signifikan terhadap profitabilitas pada model ROE, sedangkan model ROA dan GPM tidak berpengaruh signifikan. CAR berpengaruh negatif signifikan pada model ROA dan ROE. BOPO berpengaruh negatif signifikan pada model ROA dan GPM. Sedangkan pada FDR berpengaruh negatif signifikan pada model ROA. Ketiga, model yang digunakan, yakni model ROA, ROE, dan GPM, relevan untuk menjadi model estimasi profitabilitas Bank Syariah Mandiri. Dari ketiga model tersebut model ROA memiliki tiga variabel independen (CAR, BOPO, FDR) yang berpengaruh signifikan terhadap variabel dependen (ROA). Hal ini menunjukkan bahwa ROA mampu dijelaskan dengan baik oleh CAR, BOPO, dan FDR, sehingga dapat disimpulkan bahwa dalam penelitian ini model ROA merupakan model terbaik untuk mengestimasi profitabilitas pada Bank Syariah Mandiri. 


\section{Keterbatasan Penelitian}

Penelitian ini juga memiliki beberapa keterbatasan. Keterbatasan penelitian ini antara lain: pertama, rasio yang digunakan untuk menilai profitabilitas Bank Syariah Mandiri hanya terbatas pada Return on Asset (ROA), Return on Equity (ROE), dan Gross Profit Margin (GPM). Kemudian variabel yang digunakan juga terbatas hanya pada Mudharabah Musyarakah Ratio (MMR), Capital Adequacy Ratio (CAR), Biaya Operasional terhadap Pendapatan Operasional (BOPO), dan Financing to Deposit Ratio (FDR). Kedua, periode penelitian yang relatif pendek (hanya 4 tahun), sehingga relatif kurang dapat memberikan gambaran yang lebih baik. Ketiga, sebagian laporan keuangan publikasi yang digunakan ialah laporan keuangan bulanan Bank Syariah mandiri yang belum diaudit (unaudited).

Selain itu juga terdapat beberapa hal yang dapat dikembangkan dari kegiatan penelitian yang dilakukan ini. Antara lain adalah Rasio profitabilitas yang digunakan bisa menggunakan rasio alternatif lainnya seperti Net Operating Margin (NOM), banks portion of income as a percentage of total assets (BITA), net profit before tax as a percentage of Total Assets (BTTA). Sedangkan untuk variabel independen bisa menggunakan rasio lainnya serta menambah variabel independen yang berasal dari eksternal bank syariah (seperti inflasi, GDP growth, dll) karena profitabilitas bank syariah tidak hanya dipengaruhi oleh kondisi internal saja, tetapi juga kondisi eksternal. Selain itu periode penelitian juga perlu ditambah agar hasil yang diperoleh menjadi lebih baik dan representatif.

\section{DAFTAR PUSTAKA}

Harahap, S. S., Wiroso, dan Yusuf, M. (2010). Akuntansi Perbankan Syariah. Jakarta: LPFE Usakti.

Karim, A. (2004). Bank Islam: Analisis Fiqih dan Keuangan. Jakarta: Divisi Perguruan Tinggi.

Kasmir. (2007). Manajemen Perbankan. Jakarta: Rajagrafindo Persada.

Kuswandi. (2005). Meningkatkan Laba melalui Pendekatan Akuntansi Keuangan dan Akuntansi Biaya. Jakarta: Elex media Komputindo.

Najmudin. (2011). Manajemen Keuangan dan Aktualisasi Syar’iyyah Modern. Yogyakarta: Andi.

Samad, A., dan Hassan, M. K. (1999). The Performance of Malaysian Islamic Bank during 19841997: An Exploratory Study. International Journal of Islamic Fiancial Services. Vol. 1 No. 3. 